\title{
Texture, flavor, and sensory quality of buffalo milk Cheddar cheese as influenced by reducing sodium salt content
}

\author{
M. A. Murtaza, ${ }^{* 1}$ N. Huma, $†$ A. Sameen, $\dagger$ M. S. Murtaza,† S. Mahmood, ${ }^{*}$ G. Mueen-ud-Din, ${ }^{*}$ and A. Meraj* \\ *Institute of Food Science and Nutrition, University of Sargodha, Sargodha-40100, Pakistan \\ †National Institute of Food Science and Technology, University of Agriculture, Faisalabad-38040, Pakistan
}

\begin{abstract}
The adverse health effects of dietary sodium demand the production of cheese with reduced salt content. The study was aimed to assess the effect of reducing the level of sodium chloride on the texture, flavor, and sensory qualities of Cheddar cheese. Cheddar cheese was manufactured from buffalo milk standardized at $4 \%$ fat level by adding sodium chloride at 2.5, 2.0, 1.5, 1.0, and $0.5 \%$ (wt/wt of the curd obtained). Cheese samples were ripened at 6 to $8^{\circ} \mathrm{C}$ for $180 \mathrm{~d}$ and analyzed for chemical composition after $1 \mathrm{wk}$; for texture and proteolysis after 1, 60, 120, and $180 \mathrm{~d}$; and for volatile flavor compounds and sensory quality after $180 \mathrm{~d}$ of ripening. Decreasing the salt level significantly reduced the salt-in-moisture and $\mathrm{pH}$ and increased the moisture-innonfat-substances and water activity. Cheese hardness, toughness, and crumbliness decreased but proteolysis increased considerably on reducing the sodium content and during cheese ripening. Lowering the salt levels appreciably enhanced the concentration of volatile compounds associated with flavor but negatively affected the sensory perception. We concluded that salt level in cheese can be successfully reduced to a great extent if proteolysis and development of off-flavors resulted by the growth of starter and nonstarter bacteria can be controlled.
\end{abstract}

Key words: Cheddar cheese, sodium salt, texture, flavor, sensory quality

\section{INTRODUCTION}

Cow milk is under focus in most of the studies on milk, although milk of other species, such as sheep, goats, camels, and buffaloes, has nutritional potential in the human diet in different parts of the world (Ménard et al., 2010). Globally, Cheddar-type cheese is manu-

Received February 13, 2014.

Accepted July 9, 2014.

${ }^{1}$ Corresponding author: anjum_ft@yahoo.com or mian.anjum@uos. edu.pk factured from cow milk; however, buffalo milk is at the top in milk production of Pakistan. India and Pakistan together produce more than $80 \%$ of the world's buffalo milk (Murtaza et al., 2012). It is more nutritious, being richer in lactose, fat, protein, calcium, magnesium, inorganic phosphate, and vitamins compared with cow milk (Ahmad et al., 2008). On account of its composition, buffalo milk offers exceptional prospects for the manufacture of different milk products (Murtaza et al., 2008).

Cheddar is a nutritious, hard type of cheese. It endures substantial modifications on account of ripening, which is the consequence of glycolysis, lipolysis, and proteolysis (Farkye 2004; Murtaza et al., 2012). These microbial and biochemical reactions are the foundation for development of flavor, texture, and sensory perception of cheese (Lucey and Singh 2003; Smit et al. 2005; Murtaza et al., 2013).

Sodium salt is extensively and effectively used as a preservative and flavor enhancer. Its concentration is imperative for physicochemical and sensory characteristics of dairy foods, particularly cheese (Mendil, 2006). Sodium chloride affects the compositional profile of cheese as well as water activity, microbial growth and activity of enzymes, curd syneresis, and solubility and hydration of protein during the course of ripening, leading the synchronized improvement in flavor and texture (Johnson et al., 2009; Murtaza et al., 2012; Rulikowska et al., 2013).

Consuming sodium contributes to the progression of hypertension, a predecessor for disorders, such as cardiovascular problems, leading to increased risk of heart attacks or strokes in many people (Cotugna and Wolpert, 2011; Grummer et al., 2013). Traditionally, the level of sodium salt in Cheddar-type cheese is about $2.0 \%$. However, because of its adverse health effects, great demand exists to reduce the salt levels in cheese manufacturing (Rulikowska et al., 2013).

Keeping the particulars mentioned above in vision, this study was aimed to assess the effect of reducing the level of sodium chloride on water activity, proteolysis, texture, flavor, and sensory quality of Cheddar cheese prepared from buffalo milk. 
MATERIALS AND METHODS

\section{Manufacturing and Ripening of Cheddar Cheese}

Buffalo milk was obtained from the dairy farm at the University of Agriculture (Faisalabad, Pakistan) and standardized to a $4.0 \%$ fat level. Cheddar cheese was manufactured using commercially available freezedried mesophilic starter cultures (Lactococcus lactis ssp. cremoris and Lactococcus lactis ssp. lactis) and by adding sodium chloride at 2.5, 2.0, 1.5, 1.0, and $0.5 \%$ (wt/wt of the curd obtained), following the standard procedure described by Murtaza et al. (2012). Cheese samples were ripened at 6 to $8^{\circ} \mathrm{C}$ for $180 \mathrm{~d}$.

\section{Chemical Composition}

One-week-old cheese was grated and analyzed for salt $(\mathrm{NaCl})$, moisture, fat, protein, ash, $\mathrm{pH}$, salt-in-moisture, fat-in-DM, and moisture-in-nonfat-substances in triplicate samples. Salt (by titration), moisture (oven drying), fat (Babcock method), protein (Kjeldahl method), and ash (ignition) content were determined as described by Kirk and Sawyer (1991). The pH was measured with a digital pH meter (Ong et al. 2007).

\section{Proteolysis}

Proteolysis in cheese samples was assessed at $60-\mathrm{d}$ intervals during ripening using HPLC, following the procedure detailed by Hickey et al. (2006) and modified by Rulikowska et al. (2013). Five grams of cheese was homogenized in $20 \mathrm{~mL}$ of $0.1 M$ citrate buffer at $\mathrm{pH} 3.6$ at $40^{\circ} \mathrm{C}$ for $1 \mathrm{~h}$ to separate the fat. The whole suspension was centrifuged at $3,000 \times g$ for $30 \mathrm{~min}$ at $4^{\circ} \mathrm{C}$. The resulting pellet $(100 \mathrm{mg})$ was dissociated in 5 $\mathrm{mL}$ of disassociating solution and held in a water bath at $40^{\circ} \mathrm{C}$ for $1 \mathrm{~h}$ with periodic mixing. This mixture was then centrifuged at $20,000 \times g$ for $10 \mathrm{~min}$ at room temperature and filtered through a nylon $0.45-\mathrm{mm}$ syringe filter. An aliquot of $20 \mathrm{~mL}$ was injected into a Shimadzu liquid chromatograph (LC-10 AT VP series; Shimadzu Corp., Kyoto, Japan) with a UV-visible detector at 214 $\mathrm{nm}$ (Shimadzu Corp.). Separation was achieved using a gradient of 2 mobile phases: (A) 90\% water and 10\% acetonitrile with $0.1 \%$ trifluoroacetic acid and (B) $90 \%$ acetonitrile and $10 \%$ water with $0.1 \%$ trifluoroacetic acid at a flow rate of $0.8 \mathrm{~mL} / \mathrm{min}$. The gradient was $75 \%$ A for $12 \mathrm{~min}$, reduced to $51 \%$ A over $31 \mathrm{~min}$, a further reduction to $20 \%$ A over the next 13 min, held at $20 \% \mathrm{~A}$ for another $3 \mathrm{~min}$, and then an increase to $75 \%$ A over 3 min and held at this concentration for a further $2 \mathrm{~min}$; the total run time was $54 \mathrm{~min}$. The column was a C4 Jupiter 5 mm 300 A column (Shimadzu Corp.).

\section{Texture Profile Analysis}

The effect of salt addition on the texture of Cheddar cheese was evaluated after $1,60,120$, and $180 \mathrm{~d}$ of ripening by performing the texture profile analysis of the cheese samples on a texture analyzer (Stable Micro Systems Ltd., Godalming, UK), using compression plate probe P-75 as described by O'Mahony et al. (2005).

\section{Volatile Flavor Compounds}

The volatile compounds of Cheddar cheeses with varying salt levels were isolated using a dynamic headspace analyzer coupled with a gas chromatograph (Agilent Technologies Ireland Ltd., Little Island, Co. Cork, Ireland). The samples were prepared using the procedure of Rulikowska et al. (2013). The trapped volatiles were injected to the column of the gas chromatograph equipped with a capillary column. Mean peak areas were calculated for individual compounds using the Chemstation software and standard library (Agilent Technologies Ireland Ltd.). Volatiles analyses were performed in triplicate after $180 \mathrm{~d}$ of ripening.

\section{Sensory Evaluation}

Cheddar cheese samples was evaluated for sensory characteristics (odor, flavor, texture, mouthfeel, and overall acceptability) after $180 \mathrm{~d}$ of ripening on a hedonic rating scale (0-9) by a panel of 10 assessors drawn from faculty members and postgraduate students, as described by Awad et al. (2004). The samples awarded scores less than 5 were considered as of low quality.

\section{Statistical Analysis}

Each treatment (salt level) of cheese was produced in triplicate $(\mathrm{n}=3)$. The results obtained from different parameters (no. of factors 1 and 2) were subjected to statistical analysis by ANOVA under a completely randomized design, as described by Steel et al. (1997).

\section{RESULTS AND DISCUSSION}

\section{Cheese Composition}

The compositional profile of Cheddar cheese is illustrated in Table 1. The cheese samples were significantly different in salt concentration as per addition of salt during manufacturing. Notably the reduction in sodium chloride content significantly decreased the losses of salt in whey. The noncomparative increase in salt uptake might be because of the associated variation in level of whey discharged from the curd after salt addition. As 


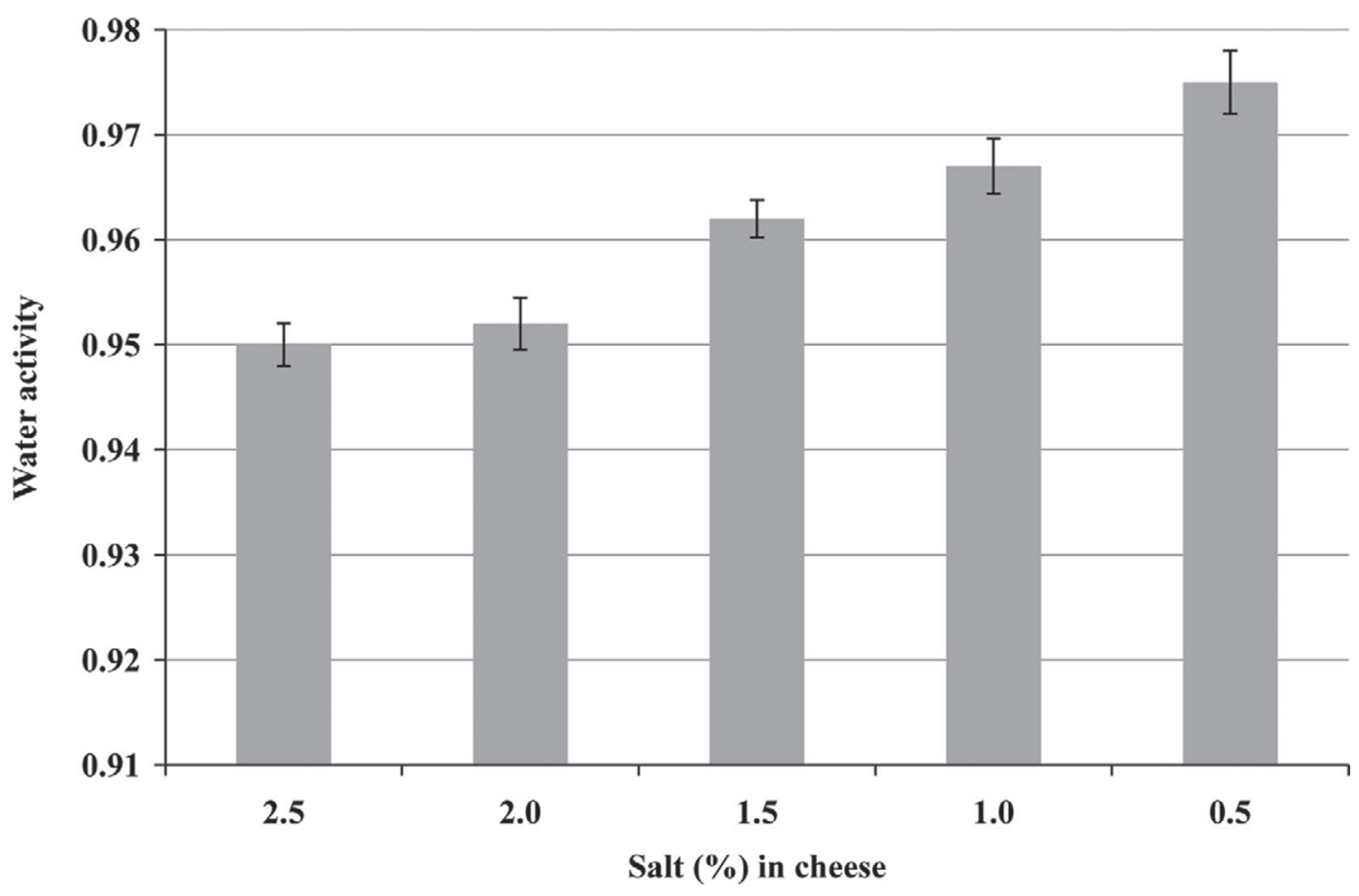

Figure 1. Water activity (means of triplicate determinations $\pm \mathrm{SD}$ ) in cheese with reduced sodium salt content.

expected, salt concentration significantly affected the cheese composition. These findings are in agreement with those reported previously (Schroeder et al., 1988; Rulikowska et al., 2013). Overall, the reduction in salt levels resulted in decreasing the protein, fat, ash, and salt-in-moisture contents and the $\mathrm{pH}$, and increasing the moisture, fat-in-DM, and moisture-in-nonfat-substances contents. As per increase in moisture, the fat and protein contents decreased because of attenuation effects. The $\mathrm{pH}$ of cheese samples ranged from 4.88 to 5.12 and decreased with decreased the sodium salt content. The $\mathrm{pH}$ of cheese is reliant on starter cultures, acidification, the $\mathrm{pH}$ when the whey is drained, and the salt-in-moisture content (Rulikowska et al., 2013).
Similar to the starter cultures, the acidification rate and $\mathrm{pH}$ at drainage were alike for all samples; the $\mathrm{pH}$ was influenced by salt-in-moisture content.

\section{Water Activity}

The mean water activity $\left(\mathbf{a}_{\mathrm{w}}\right)$ in cheese was significantly $(P<0.05)$ influenced by the reduction in salt content (Figure 1). The $\mathrm{a}_{\mathrm{w}}$ is affected by the moisture and solute contents in cheese (Guinee and Fox, 2004). The $\mathrm{a}_{\mathrm{w}}$ increased with reduced sodium salt content as a result of increases in the moisture-in-nonfat-substances content. Cheese samples having 2.5 and $2.0 \%$ sodium chloride content had a statistically nonsignificant $(P>$

Table 1. Compositional profile of Cheddar cheese

\begin{tabular}{lccccc}
\hline & \multicolumn{5}{c}{ Salt (\%) in cheese samples } \\
\cline { 2 - 6 } Item & 2.5 & 2.0 & 1.5 & 1.0 & 0.5 \\
\hline Composition (\%) & $1.84^{\mathrm{a}}$ & $1.42^{\mathrm{b}}$ & $1.22^{\mathrm{c}}$ & $0.85^{\mathrm{d}}$ & $0.45^{\mathrm{e}}$ \\
Salt & $37.98^{\mathrm{d}}$ & $38.14^{\mathrm{cd}}$ & $38.88^{\mathrm{c}}$ & $39.84^{\mathrm{b}}$ & $40.90^{\mathrm{a}}$ \\
Moisture & 31.45 & 31.22 & 30.94 & 30.60 & 30.32 \\
Fat & $25.06^{\mathrm{a}}$ & $24.82^{\mathrm{ab}}$ & $24.52^{\mathrm{b}}$ & $24.32^{\mathrm{bc}}$ & $24.18^{\mathrm{c}}$ \\
Protein & $4.02^{\mathrm{a}}$ & $3.58^{\mathrm{b}}$ & $3.36^{\mathrm{bc}}$ & $3.05^{\mathrm{c}}$ & $2.68^{\mathrm{d}}$ \\
Ash & $4.52^{\mathrm{a}}$ & $4.08^{\mathrm{ab}}$ & $3.60^{\mathrm{b}}$ & $2.58^{\mathrm{c}}$ & $1.30^{\mathrm{d}}$ \\
Salt-in-moisture & $50.64^{\mathrm{d}}$ & $51.20^{\mathrm{cd}}$ & $51.70^{\mathrm{c}}$ & $52.14^{\mathrm{b}}$ & $52.90^{\mathrm{a}}$ \\
Fat-in-DM & $56.55^{\mathrm{d}}$ & $57.03^{\mathrm{cd}}$ & $58.27^{\mathrm{c}}$ & $59.91^{\mathrm{b}}$ & $60.93^{\mathrm{a}}$ \\
Moisture-in-nonfat-substances & $5.12^{\mathrm{a}}$ & $5.04^{\mathrm{b}}$ & $4.98^{\mathrm{bc}}$ & $4.95^{\mathrm{bc}}$ & $4.88^{\mathrm{c}}$ \\
pH & & &
\end{tabular}

${ }^{\mathrm{a} e}$ Values with the same superscript letters within a row do not differ significantly at a significance level of $5 \%$. 
a)

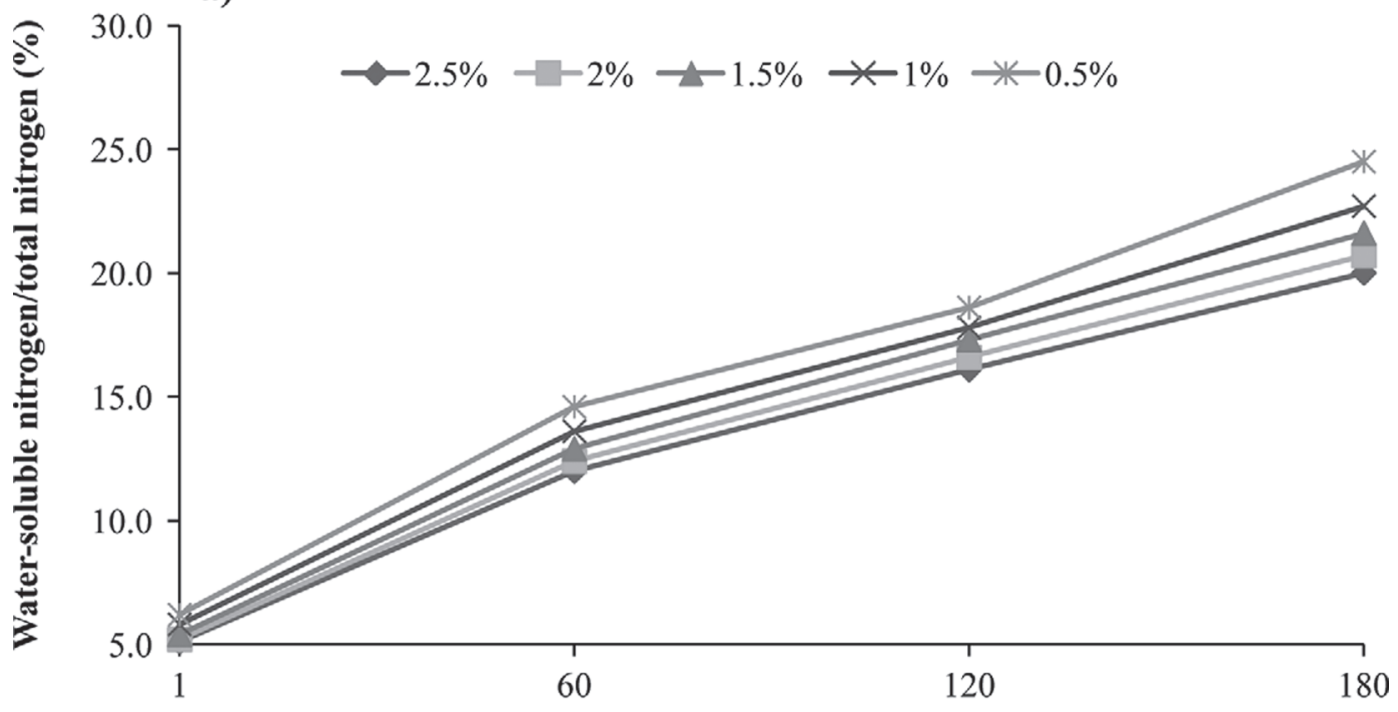

b)

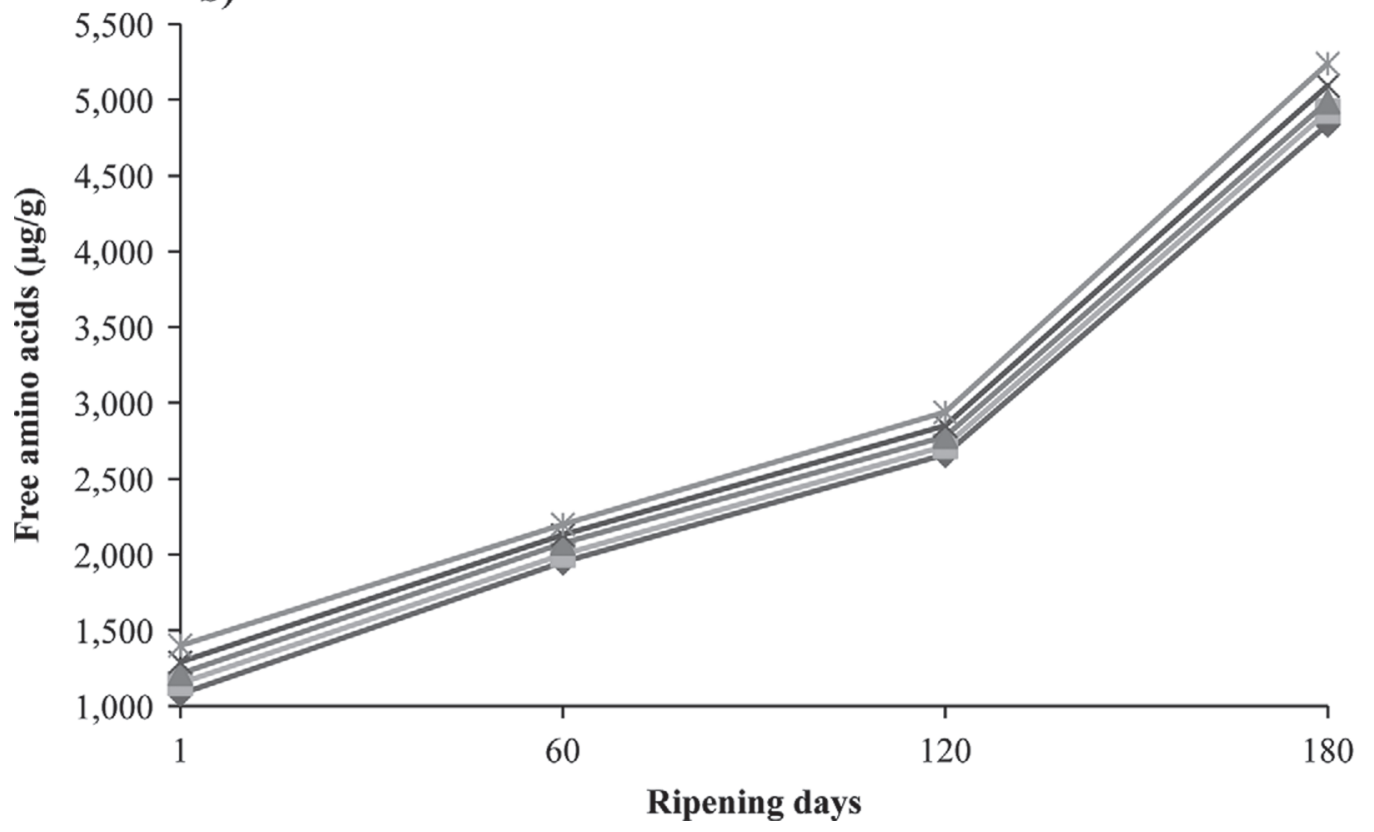

Figure 2. Proteolysis in Cheddar cheese containing 0.5, 1.0, 1.5, 2.0 or 2.5\% salt. (a) Water-soluble nitrogen as a percentage of total nitrogen; (b) total free amino acid content.

0.05) difference in $\mathrm{a}_{\mathrm{w}}$, probably because of the nonsignificant difference in protein content, which influences the water-holding capacity of the cheese. The variations in $\mathrm{a}_{\mathrm{w}}$ significantly influenced proteolysis because the microbial and enzymatic activities are associated with $\mathrm{a}_{\mathrm{w}}$ (Choisy et al., 2000; Lawrence et al., 2004).

\section{Proteolysis}

The decrease in sodium salt content significantly increased proteolysis (Figure 2a), as anticipated based on the reported literature (Kelly et al., 1996; Rulikowska et al., 2013). The escalation in proteolysis might be primarily the result of more bacterial and enzymatic activities due to the higher moisture and moisture-innonfat-substances contents and greater $\mathrm{a}_{\mathrm{w}}$ (Guinee, 2004). In general, significant differences $(P<0.05)$ were found for mean values of water-soluble nitrogen $(\mathrm{pH}$ 4.6) at each point during ripening between the cheese samples. The level of primary proteolysis was considerably higher for samples having lower salt concentration and pointedly lower for cheese with higher 

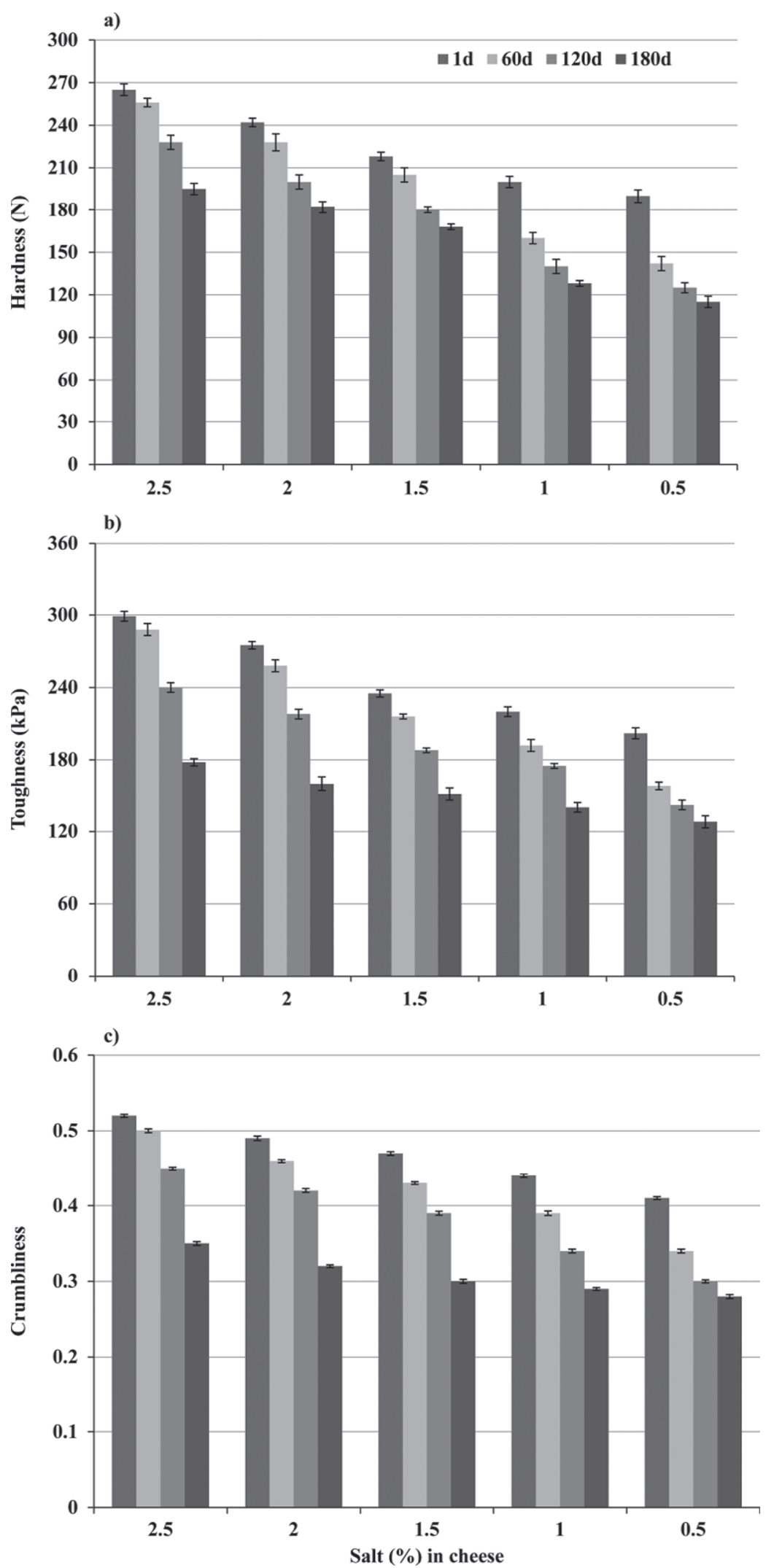

Figure 3. Texture profile (means of triplicate determinations $\pm \mathrm{SD}$ ) of Cheddar cheese as influenced by reduced salt content and ripening for up to $180 \mathrm{~d}$. (a) Cheese hardness; (b) cheese toughness; (c) cheese crumbliness. 
Table 2. Volatile flavor compounds in Cheddar cheese (average peak areas in arbitrary units $\times 10,000$ )

\begin{tabular}{|c|c|c|c|c|c|}
\hline \multirow[b]{2}{*}{ Volatile flavor compound } & \multicolumn{5}{|c|}{ Salt (\%) in cheese samples } \\
\hline & 2.5 & 2.0 & 1.5 & 1.0 & 0.5 \\
\hline \multicolumn{6}{|l|}{ Alcohol } \\
\hline Ethanol & 88,345 & 99,723 & 74,982 & 76,025 & 80,452 \\
\hline Propanol & 1,550 & 1,892 & 8,550 & 20,855 & 60,826 \\
\hline 1-Butanol & 105 & 112 & 138 & 650 & 1,890 \\
\hline 2-Butanol & 1,856 & 2,508 & 10,520 & 58,470 & 75,082 \\
\hline Hexanol & 305 & 682 & 220 & 185 & 274 \\
\hline Heptanol & 10 & 28 & 52 & 86 & 148 \\
\hline \multicolumn{6}{|l|}{ Aldehyde } \\
\hline Pentanal & 412 & 404 & 395 & 428 & 400 \\
\hline Hexanal & 198 & 173 & 140 & 122 & 104 \\
\hline Heptanal & 76 & 81 & 88 & 105 & 156 \\
\hline Octanal & 36 & 40 & 51 & 69 & 82 \\
\hline \multicolumn{6}{|l|}{ Ketone } \\
\hline Butanone & 8,210 & 14,728 & 17,090 & 19,453 & 24,028 \\
\hline Pentanone & 724 & 480 & 210 & 136 & 98 \\
\hline Hexanone & 154 & 182 & 170 & 306 & 582 \\
\hline Heptanone & 422 & 380 & 316 & 256 & 176 \\
\hline \multicolumn{6}{|l|}{ Ester } \\
\hline Ethyl acetate & 2,698 & 2,840 & 2,903 & 3,276 & 3,687 \\
\hline Ethyl butanoate & 1,892 & 1,863 & 1,906 & 1,875 & 1,952 \\
\hline Ethyl hexanoate & 174 & 188 & 200 & 222 & 264 \\
\hline \multicolumn{6}{|l|}{ Sulfur compounds } \\
\hline Dimethyl disulfide & 512 & 568 & 670 & 792 & 910 \\
\hline Dimethyl trisulfide & 12 & 18 & 58 & 70 & 78 \\
\hline
\end{tabular}

salt content. The greater degree of primary proteolysis in Cheddar cheese having less sodium chloride added was established by greater breakdown of caseins by proteases, which is in agreement with Kelly et al. (1996) and Mistry and Kasperson (1998).

Regarding the free amino acids, the reduction in the salt content considerably increased the levels (Figure $2 \mathrm{~b})$. Significant differences $(P<0.05)$ were found in the total free amino acids content at each salt concentration added during the early phases of ripening. These differences remained throughout the course of ripening; however, they were inconsistent. This might be because of changes in proteolysis (Rulikowska et al., 2013).

\section{Texture Profile Analysis}

The texture profile analysis of Cheddar cheese showed that the hardness, toughness, and crumbliness decreased upon reducing the sodium salt concentration and with the process of ripening (Figure 3) The textural parameters were significantly $(P<0.05)$ influenced by the salt levels, ripening time, and their interaction. The cheeses having 0.5 or $1.0 \%$ salt content added could be categorized as soft body cheeses compared with the other treatments.

It is recognized that the increased proteolysis and moisture-in-nonfat-substances affect the cheese texture (Mistry and Kasperson, 1998; Guinee, 2004) and result in decreasing the hardness, toughness, and crumbli- ness. Moreover, casein hydration was also found to be involved in the development of cheese texture. The salt addition in cheese improves casein hydration as well as the volume of the matrix and solubilization of casein through calcium displacement by sodium ions (Guinee, 2004). Thus, in the present study, the decrease in sodium salt content might have led to a decease in calcium displacement and reduced casein solubilization, resulting in less casein hydration; a decreased displacement of calcium and reduced casein solubilization, leading to less casein hydration because of the reduced sodium chloride content in cheese was also reported by Rulikowska et al. (2013).

Sodium salt also ultimately controls the textural characteristics indirectly through its influence on cheese $\mathrm{pH}$, which has an effect on starter and enzyme activities (Lawrence et al., 2004).

\section{Volatile Flavor Compounds}

About 19 flavor compounds, including 6 alcohols, 4 aldehydes, 4 ketones, 3 esters, and 2 sulfur compounds were detected in volatile analysis of the Cheddar cheeses. All these compounds have previously been detected in Cheddar-type cheese (Singh et al., 2003). Cheese samples having lower sodium salt content were found to have a higher concentration of volatile compounds, as depicted by the average peak areas (Table 2). However, the quantity of ethanol increased upon increasing the 
Table 3. Sensory evaluation (scores) of Cheddar cheese ${ }^{1}$

\begin{tabular}{llllll}
\hline & \multicolumn{5}{c}{ Salt (\%) } \\
\cline { 2 - 6 } Parameter cheese samples \\
\cline { 2 - 6 } & 2.5 & 2.0 & 1.5 & 1.0 & 0.5 \\
\hline Odor & $6.7^{\mathrm{b}}$ & $7.8^{\mathrm{a}}$ & $6.5^{\mathrm{b}}$ & $6.0^{\mathrm{c}}$ & $5.2^{\mathrm{d}}$ \\
Flavor & $8.0^{\mathrm{a}}$ & $7.6^{\mathrm{b}}$ & $6.8^{\mathrm{c}}$ & $6.2^{\mathrm{d}}$ & $5.0^{\mathrm{e}}$ \\
Texture & $7.4^{\mathrm{a}}$ & $7.6^{\mathrm{a}}$ & $7.0^{\mathrm{b}}$ & $6.5^{\mathrm{c}}$ & $5.6^{\mathrm{d}}$ \\
Mouthfeel & $7.5^{\mathrm{ab}}$ & $7.8^{\mathrm{a}}$ & $7.2^{\mathrm{b}}$ & $6.5^{\mathrm{c}}$ & $6.0^{\mathrm{d}}$ \\
Overall acceptability & $7.6^{\mathrm{a}}$ & $7.7^{\mathrm{a}}$ & $6.8^{\mathrm{b}}$ & $6.3^{\mathrm{c}}$ & $5.4^{\mathrm{d}}$ \\
\hline
\end{tabular}

${ }^{a-e}$ Values with the same superscript letters within a row indicate that samples do not differ significantly at a significance level of $5 \%$.

${ }^{1}$ Sensory evaluation was done on a hedonic rating scale (0-9) by a panel of 10 assessors. Samples awarded scores less than 5 were considered as of low quality.

salt level, as the highest peak area of ethanol was in cheese with $2.5 \%$ added salt.

The characteristic properties of all these compounds in cheese flavor are recognized, except the ketones, which are the direct outcome of oxidation of FFA during lipolysis (Reineccius, 1999). These ketones are mostly related to fruit- or ether-like flavors in Cheddar cheese (Singh et al., 2003) and are the precursors of alcohols and aldehydes, which make great contributions to cheese flavor. The aldehydes, alcohols, and ethyl esters are the outcomes of reduction of FFA, amino acid metabolism, and reaction of FFA and alcohols, respectively. The former are found to be linked with oily, fatty, pungent, and soapy flavors (Singh et al., 2003). Sulfur compounds are instigated from the metabolic changes in sulfur-containing amino acids, such as methionine, and are connected with onion-, cabbage-, and garlic-like volatiles (McSweeney and Sousa, 2000; Williams et al., 2001).

The higher concentration of volatiles in cheese with less added sodium salt must be due to the early growth of starter and nonstarter bacteria and enzymatic activity, as salt addition to cheese exerts control on bacterial growth, enzymatic activities, and reactions during ripening; hence, salt addition regulates the development of flavor and aroma (Murtaza et al., 2012). The discrepancies in flavor profiles of cheeses having lower and higher quantities of added salt are likely due to the changes in composition.

\section{Sensory Evaluation}

The reduction in salt added greatly influenced the sensory perception of the cheese samples. Statistical analysis of the scores awarded (0-9) showed significant variation $(P<0.05)$ among all samples. The samples having $2.0 \%$ added salt were liked and scored the highest (Table 3). Although the volatile flavor compounds had higher concentrations in cheese with lower salt concentrations, the sensory flavor perceptions were the highest for cheese with $2.5 \%$ added salt, with a gradual decrease as salt contents reduced.

Drake et al. (2001) described that "sweetness" is normally inversely associated with "bitterness." This concurs with the findings of the current study, as bitterness caused by nonstarter bacteria was counteracted by the addition of salt and, hence, a sweet perception resulted. The increased hydrolysis of caseins relates to augmented bitterness, probably due to the decreased aggregation of caseins upon reducing sodium salt content (Guinee and O'Kennedy, 2007).

\section{CONCLUSIONS}

We concluded that reducing the sodium chloride content has a substantial effect on cheese composition and proliferation of proteolysis, and increases the $\mathrm{a}_{\mathrm{w}}$ and volatile flavor compounds content, but decreases the sensory discernment. Regarding the texture, hardness, toughness, and crumbliness lessened upon reducing the salt content and during the course of ripening. Hence, quality Cheddar cheese can be manufactured with reduced sodium salt content by controlling and monitoring the proteolysis and $\mathrm{a}_{\mathrm{w}}$.

\section{REFERENCES}

Ahmad, S., I. Gaucher, F. Rousseau, E. Beaucher, M. Piot, J. F. Grongnet, and F. Gaucheron. 2008. Effects of acidification on physico-chemical characteristics of buffalo milk: A comparison with cow's milk. Food Chem. 106:11-17.

Awad, R. A., L. B. Abdel-Hamid, S. A. El-Shabrawy, and R. K. Singh. 2004. Physical and sensory properties of block processed cheese with formulated emulsifying salt mixtures. Int. J. Food Prop. $7: 429-448$.

Choisy, C., M. Desmazeaud, J. C. Gripon, G. Lamberet, and J. Lenoir. 2000. The biochemistry of ripening. Pages $82-151$ in Cheese Making: From Science to Quality Assurance. 2nd ed. A. Eck and J. C. Gillis, ed. Lavoisier, Paris, France.

Cotugna, N., and S. Wolpert. 2011. Sodium recommendations for special populations and the resulting implications. J. Community Health 36:874-882.

Drake, M. A., S. C. McIngvale, P. D. Gerard, K. R. Cadwallader, and G. V. Civille. 2001. Development of a descriptive language for Cheddar cheese. J. Food Sci. 66:1422-1427. 
Farkye, N. Y. 2004. Cheese technology. Int. J. Dairy Technol. 57:9198.

Grummer, J., N. Bobowski, M. Karalus, Z. Vickers, and T. Schoenfuss. 2013. Use of potassium chloride and flavor enhancers in low sodium Cheddar cheese. J. Dairy Sci. 96:1401-1418.

Guinee, T. P. 2004. Salting and role of salt in cheese. Int. J. Dairy Technol. 57:99-109.

Guinee, T. P., and P. F. Fox. 2004. Salt in cheese: Physical, chemical and biological aspects. Pages 210-262 in Cheese: Chemistry, Physics and Microbiology. Vol. 1. 3rd ed. P. F. Fox, P. L. H. McSweeney, T. M. Cogan, and T. P. Guinee ed. Elsevier Academic Press, London, UK

Guinee, T. P., and B. T. O'Kennedy. 2007. Reducing salt in cheese and dairy spreads. Pages 316-357 in Reducing Salt in Foods: Practical Strategies. D. Kilcast and F. Angus, ed. CRC Press, Boca Raton, FL.

Hickey, D. K., K. N. Kilcawley, T. P. Beresford, E. M. Sheehan, and M. G. Wilkinson. 2006. The influence of a seasonal milk supply on the biochemical and sensory properties of Cheddar cheese. Int. Dairy J. 16:679-690.

Johnson, M. E., R. Kapoor, D. J. McMahon, D. R. McCoy, and R. G. Narasimmon. 2009. Reduction of sodium and fat levels in natural and processed cheeses: Scientific and technological aspects. Comp. Rev. Food Sci. Food Safety 8:252-268.

Kelly, M., P. F. Fox, and P. L. H. McSweeney. 1996. Effect of saltin-moisture on proteolysis in Cheddar-type cheese. Milchwissenschaft 51:498-501.

Kirk, R. S., and R. Sawyer. 1991. Pearson's Composition Analysis of Food. Addison-Wesley Longman Ltd., Harlow, UK.

Lawrence, R. C., J. Gilles, L. K. Creamer, V. L. Crow, H. A. Heap, and C. G. Honoré. 2004. Cheddar cheese and related dry-salted cheese varieties. Pages 71-102 in Cheese: Chemistry, Physics and Microbiology: Volume 2: General Aspects, Major Cheese Groups. 3rd ed. P. F. Fox and P. L. H. McSweeney, ed. Elsevier Academic Press, London, UK.

Lucey, J. A., and H. Singh. 2003. Acid coagulation of milk. Pages 1001-1025 in Advanced Dairy Chemistry. Vol. 1. 3rd ed. P. F. Fox and P. L. H. McSweeney, ed. Kluwer Academic, Plenum Publishers, New York, NY.

McSweeney, P. L. H., and M. J. Sousa. 2000. Biochemical pathways for the production of flavour compounds in cheese during ripening: A review. Lait 80:293-324.

Ménard, O., S. Ahmad, F. Rousseau, V. Briard-Bion, F. Gaucheron, and C. Lopez. 2010. Buffalo vs. cow milk fat globules: Size distribution, zeta-potential, compositions in total fatty acids and in polar lipids from the milk fat globule membrane. Food Chem. 120:544-551.
Mendil, D. 2006. Mineral and trace metal levels in some cheese collected from Turkey. Food Chem. 96:532-537.

Mistry, V. V., and K. M. Kasperson. 1998. Influence of salt on the quality of reduced fat Cheddar cheese. J. Dairy Sci. 81:1214-1221.

Murtaza, M. A., S. U. Rehman, F. M. Anjum, and N. Huma. 2013. Descriptive sensory profile of cow and buffalo milk Cheddar cheese prepared using indigenous cultures. J. Dairy Sci. 96:1380-1386.

Murtaza, M. A., S. U. Rehman, F. M. Anjum, N. Huma, O. M. Tarar, and G. Mueen-ud-Din. 2012. Organic acids contents of buffalo milk Cheddar cheese as influenced by accelerated ripening and sodium salt. J. Food Biochem. 36:99-106.

Murtaza, M. A., S. U. Rehman, F. M. Anjum, and H. Nawaz. 2008. Nutritional comparison of cow and buffalo milk Cheddar cheese. Pakistan J. Nutr. 7:509-512.

O'Mahony, J. A., J. A. Lucey, and P. L. H. McSweeney. 2005. Chymosin-mediated proteolysis, calcium solubilization, and texture development during the ripening of Cheddar cheese. J. Dairy Sci. 88:3101-3114.

Ong, L., A. Henriksson, and N. P. Shah. 2007. Proteolytic pattern and organic acid profiles of probiotic Cheddar cheese as influenced by probiotic strains of Lactobacillus acidophilus, Lb. paracasei, Lb. casei or Bifidobacterium sp. Int. Dairy J. 17:67-78.

Reineccius, G. A. 1999. Flavor chemistry. Pages 61-115 in Source Book of Flavors. 2nd ed. G. A. Reineccius, ed. Aspen Publishers Inc., Gaithersburg, MD.

Rulikowska, A., K. N. Kilcawley, I. A. Doolan, M. Alonso-Gomez, A. B. Nongonierma, J. A. Hannon, and M. G. Wilkinson. 2013. The impact of reduced sodium chloride content on Cheddar cheese quality. Int. Dairy J. 28:45-55.

Schroeder, C. L., F. W. Bodyfelt, C. J. Wyatt, and M. R. McDaniel. 1988. Reduction of sodium chloride in Cheddar cheese: Effect on sensory, microbiological, and chemical properties. J. Dairy Sci. 71:2010-2020.

Singh. T. K., M. A. Drake, and K. R. Cadwallader. 2003. Flavor of Cheddar cheese: A chemical and sensory perspective. Comp. Rev. Food Sci. Food Safety 2:139-162.

Smit, G., B. A. Smit, and W. J. M. Engels. 2005. Flavour formation by lactic acid bacteria and biochemical flavour profiling of cheese products. FEMS Microbiol. Rev. 29:591-610.

Steel, R. G. D., J. H. Torrie, and D. A. Dickey. 1997. Principles and Procedures of Statistics. A Biometrical Approach. 3rd ed. McGraw Hill Book Co. Inc., New York, NY.

Williams, A. G. J. Noble, and J. M. Banks. 2001. Catabolism of amino acids by lactic acid bacteria isolated from Cheddar cheese. Int. Dairy J. 11:203-215. 